\title{
Effect of Adding Lemon Peels Powder on Some Quality Properties of Minced Beef Patty during Refrigerated Storage
}

\author{
Hayam Mohamed Ibrahim ${ }^{1 *}$, Ibrahim Mohamed Hassan ${ }^{2}$ and \\ Ahmed Abd El- Ghafar Hammed ${ }^{1}$ \\ ${ }^{1}$ Department of Food Science and Technology, Food Science and Technology, \\ National Research Centre, Egypt \\ ${ }^{2}$ Department of Food Science and Technology, Facility of Agriculture, \\ Ein Shams University, Egypt
}

Keywords

Citrus waste, lemon peel, minced beef meat patty, oxidative changes, color, metmyoglobin, microbial growth, sensory \& cooking properties

Article Info

Accepted: 30 April 2021 Available Online: 10 May 2021
The effect of adding lemon peels powder on some quality properties of minced beef patties during refrigerated storage is the objectives of the present work. Control beef patty samples (LP) exhibited significant higher TBARS values during refrigerated storage. Whereas the prepared lemon peel patties (1\% and2\% LP) samples showed good quality with lower TBARS till 9 days at $4{ }^{\circ} \mathrm{C}$. Total volatile basic nitrogen (TVBN) of patty samples gradually increased with different rates. LP 2\% samples exhibited higher antioxidant activity (AOA \%) than those treated with $1 \%$ LP. The LP $2 \%$ sample gave the greatest DPPH followed by $1 \%$ LP compared to control at zero time. The DPPH \% activity decreased during refrigerated storage in all patties samples. Concerning Met-myoglobin\%; control sample revealed the highest metmyoglobin\% estimated from $19.20 \%$ at the beginning day of storage to $76.47 \%$ at the end of the storage period. Meanwhile, 2\% LP sample gave lowest \% Met-myoglobin (40.74\%) and 1\% LP sample exhibited $47.42 \%$ Met-myoglobin at the end of storage time (12days). Noticeably the overall acceptability scores of the formulated samples increased with increasing levels of citrus peel [L.P]; where 2\% LP sample gained great acceptability more than the $1 \%$.

\section{Introduction}

Citrus processing generates a considerable amount of wastes which represent a serious environmental problem. Citrus wastes are promising sources with valuable technological and nutritional properties can be used as functional ingredients when designing healthy foods (functional foods) (Mar1'n, et al., 2002;
Puupponen-Pimia et al., 2002).They have high content of bioactive compounds and can be used as natural food additives, antioxidants, antimicrobials, colorants, flavorings and thickener agents (Ayala-Zavala et al., 2011). Therefore, these wastes may add worth for food industry benefits from nutrition and economic viewpoints, where, they give potential health protection for the consumer 
from their excellent nutritional value. On the other hand, the reused citrus waste is expected to minimize the environmental influence and add value to this waste. Natural preservatives can protect the human body from free radicals and could retard the progress of many chronic diseases as well as lipid oxidation and microbial growth in foods due to their phenolic compounds (Camo et al., 2008; APHA, 2001). Several studies on citrus waste including lemon peels [LP] noticed that they may be viable functional ingredients for different products such as meat pastes, baked goods and yoghourt. So there is interest in using lemon peels "citrus waste" as natural functional ingredients through processing healthy meat products to enhance oxidative stability and preserve meat quality for longer shelf life as maintaining food safety according to consumers demand for natural and safe products.

Minced beef is one of the most popular and acceptable meat products, that are widely consumed and used as fast meals that are highly perishable (Michalczyk et al.,2012). Microbial growth, lipid oxidation and color changes are important factors for shelf-life and consequently for consumer acceptance of fresh meat (Hayes et al., 2010; Pavelková et al., 2013). Minced meat undergo oxidative changes and develop rancidity more quickly than whole muscle, since grinding exposes more of the muscle surface to air and microbial contamination (Mitsumoto, et al., 2005). Grinding meat leads to rapid formation of met-myoglobin, undesirable brown color and oxidative rancidity (Sahoo and Anjaneyulu 1997), seriously affecting consumer acceptance. Also, oxy-myoglobin and lipid oxidation appear to be interrelated in meat (Anton et al., 1993) With prolonged storage, oxy-myoglobin oxidizes to metmyoglobin and gives meat an unattractive brown color (Djenane et al., 2002). Oxidative stability is a central parameter in the estimation of meat quality because of the susceptibility of meat products to oxidative degeneration, which is one of the main causes of spoilage. In meat products oxidative reactions are affected by several factors, including lipid composition, processing and could be delayed by endogenous or exogenous antioxidants (Sacchetti et al., 2008). In addition, lipid oxidation affects essential sensory traits of meat products, causing flavor, color and texture deterioration (Estevez et al., 2005). The shelf life of meat is related to lipid oxidation reactions, which could affect its sensory properties, causing rancidity, as well as its nutritional characteristics through the formation of potentially toxic compounds (Sacchetti et al., 2008). Moreover, oxidative processes are also associated with discoloration of meat products as lipid oxidation results in the formation of prooxidants which are capable of reacting with oxy-myoglobin and lead to formation of metmyoglobin (Frankel 1998). Therefore, color and lipid stability in meat are very important quality characteristics which influence consumer acceptability and the lipid oxidation problem has extensive economic importance for the meat industry. Several research studies indicated that oxidation in meat can be effectively controlled or at least, minimized by adding antioxidants (Djenane et al., 2004). It is known that the antioxidant is a substance that delays oxidation by inhibiting initial free radical formation or by preventing them from producing more free radicals, which can perpetuate the reaction (Fennema 1996). Also, refrigeration storage is usually the most common preservative method of meat and meat products. In order to extend refrigerated storage time, antimicrobial and antioxidant additives are added to muscle foods (Solomakos, et al., 2008). Therefore, the use of lemon peel wastes [LP] as natural food additives or supplements and as antioxidant additives for production of healthy beef products of high quality and safety as well as 
high nutritional value have gained increasing interest because these are high-value products and their recovery may be economically attractive

So, the objective of the present study was to evaluate the effectiveness of adding lemon peels powder at two levels (1 and $2 \%$ ) on some quality properties of beef patties during refrigerated storage.

\section{Materials and Methods}

Citrus lemon (Citrus aurantiifolia) fruits were purchased from an Egyptian local market. Also, fresh beef lean (from the round) and beef back fat from the same beef carcasses were purchased from a slaughter house at Egyptian local market, Giza, Egypt.

\section{Chemicals}

Chemicals, solvents, standards and reagents were purchased from Sigma Chemical Co. (St. Louis, Mo, USA). All other chemicals used were of analytical grade.

\section{Preparation of lemon peels powder}

Lemon fruits were washed by running tap water, peeled and their edible portions were carefully separated. The obtained fresh citrus peels were cut into small pieces before the drying process.

\section{Microwave- Drying Method}

A programmable domestic microwave oven (type Samsung,77 QH 400148,MF 2015), with a maximum output of $1500 \mathrm{~W}$ at $2450 \mathrm{MHz}$ was used for drying the fresh lemon peel pieces samples for $6 \mathrm{~min}$.

The dried lemon citrus peels (LP) were ground to a fine powder using a mechanical laboratory grinder and passed through a 24 - mesh sieve then packaged in polyethylene bags and stored at $4 \pm 1^{\circ} \mathrm{C}$ until required for use.

\section{Preparation of Minced beef patties}

The beef lean meat (from the round) and beef back fat were minced separately through $3 / 8$ inch plate using a laboratory meat mincer for preparing the treated minced beef patties samples. Control sample was formulated without any lemon peels addition whereas the treated patties samples were prepared by adding 5\% lemon peels suspension as follows in (Table 1). All ingredients were manually mixed by hand for $5 \mathrm{~min}$, and then, re-minced through a $1 / 4$ in. plate to be mixed uniformly. All ingredients were manually mixed by hand for $5 \mathrm{~min}$, and then, re-minced through a $1 / 4$ in. plate to be mixed uniformly. The homogenized meat mixtures were shaped into patties (approximately $50 \mathrm{~g}$ each) per treatment using a round shape patty maker (6 $\mathrm{cm} \times 2 \mathrm{~cm}$ ). Patties were analyzed as fresh samples on the manufacture day. Beef patties were placed on plastic foam meat trays, wrapped with polyethylene film then labeled and stored in a refrigerator at $4 \pm 1^{\circ} \mathrm{C}$ for 12 days. Patties were analyzed as fresh samples on the manufacture day. Each group of samples was withdrawn at three days intervals over storage period for analysis.

\section{Analytical Methods}

\section{Thiobarbituric acid reactive substances (TBARS)}

Determination of TBARS value has been found to be a good indicator for lipid oxidation in meat and meat products. TBARS values were determined in tested minced beef patties samples during refrigerated storage at $4 \pm 1^{\circ} \mathrm{C}$ to evaluate efficiency of the additives (lemon peels) as natural antioxidants according to (Pearson, 1991). Meat samples 
$(10 \mathrm{~g})$ were mixed with $50 \mathrm{~mL}$ distilled water. Then $2.5 \mathrm{~mL}$ of $4 \mathrm{M} \mathrm{HCl}$ was added to get the $\mathrm{pH}$ to 1.5 , followed by addition of antifoaming and a few glass beads. The flask was heated by means of an electric mantel and $50 \mathrm{~mL}$ distillate was collected in $10 \mathrm{~min}$ from the time of boiling commences. Five $\mathrm{mL}$ of the distillate was mixed with $5 \mathrm{~mL}$ of TBA solution $(0.2883 \mathrm{gm}$ TBA/100 $\mathrm{mL}$ of $90 \%$ glacial acetic acid) in a glass-stopper tub.

Blank was carried out using $5 \mathrm{~mL}$ distilled water and $5 \mathrm{~mL}$ TBA solution. Tubes were covered and heated in boiling water bath for $35 \mathrm{~min}$, then after rapid cooling in ice bath, absorbance at $538 \mathrm{~nm}$ was measured against the blank using ultraviolet visible scanner spectrophotometer (T80+ UV/V is Spectrophotometer PG instrument Ltd). The TBARS values were calculated by multiplying the absorbance by the factor of 7.8 and the result was represented as $\mathrm{mg}$ of malonaldehyde per kg sample.

\section{Total volatile basic nitrogen (TVBN)}

It is known that TVBN are products of bacterial decomposition and the content is extensively used as an index to assess the keeping quality and shelf life of meat and meat products (Pearson, 1991). The method recommended for determination of TVBN is based on a semi-micro distillation procedure. Weigh $10 \mathrm{gm}$ of minced meat samples plus 2gm magnesium oxide $(\mathrm{MgO})$ into a semimicro-distillation apparatus, and then add 300 $\mathrm{mL}$ tap water and antifoam materials. Steam distilled collect in $25 \mathrm{~mL} 2 \%$ boric acid containing kjeldahl indicator solution which exhibited blue color. Kjeldahl flask was heated for $10 \mathrm{~min}$, then distillate for another $15 \mathrm{~min}$ from the time of boiling commences, so $\sim 150 \mathrm{~mL}$ distillate was collected into boric containing flask, the color became light green after fixing the ammonia "NH3". Titrate to a pale blue end point with $0.1 \mathrm{~N} \mathrm{H}_{2} \mathrm{SO}_{4}$ solution.
The TVBN values were calculated by multiplying the reading minus the blank by the factor of 14.The results were represented as mg N per 100 gm sample.

TVBN value

$=\underline{\text { volume } \mathrm{HCl} \times 14 \times \mathrm{N} \mathrm{HCl} \times 100}$

weight sample $(\mathrm{g})$

\section{Antioxidant activity}

The antioxidant potential expressed in terms of percentage of antioxidant activity (AOA \%) was calculated by the following equation (Wijewickreme and Kitts, 1998):
AOA \%
[TBARS value - TBARS of] $\times 100$
of the control the test sample

TBARS value of the control

\section{Radical scavenging activity (DPPH)}

The effect of used lemon citrus peel extracts on 1,1-diphenyl-2-picrylhydrazyl (DPPH) free radical was estimated in order to assess the antioxidant capacity according to the procedure described by (Yi et al., 2008) ${ }^{3}$ with some modifications. The reaction mixture was incubated for $30 \mathrm{~min}$ in darkness at room temperature. The absorbance of the resulting solution was measured at $517 \mathrm{~nm}$ using spectrophotometer (T80 UV/ Visible - PG instrument Ltd, Made in Germany). For the control, the assay was conducted in the same manner using ethanol instead of sample solution. DPPH scavenging capacity of the tested samples was measured as a decrease in the absorbance and was calculated by using the following equation:

Scavenging activity $(\%)=$ Ac - As $/$ Ac X100

Where Ac and As are the absorbance's at 517 $\mathrm{nm}$ of the control and sample, respectively. 
Microbiological preparation of medium used for T.P.C

Total plate count (T.P.C) of the control and treated beef samples were evaluated by plating on nutrient agar medium (N.A) according to the recommended method of (Frazier and Foster, 1950), However, its composition was prepared according to the method described by Difco Manual (1998) as follows: Beef extract $(3 \mathrm{gm})$, sodium chloride $(5 \mathrm{gm})$, peptone $(5 \mathrm{gm})$, agar $(15 \mathrm{gm})$, distilled water up to $(1 \mathrm{~L})$ and modified $\mathrm{pH}$ of the medium to $6.8 \pm 0.2$.

These ingredients were mixed thoroughly, boiled to dissolve them then dispensed into flasks and autoclaved at $121^{\circ} \mathrm{C}$ for $15 \mathrm{~min}$ and then cool to about $45^{\circ} \mathrm{C}$ and pour into sterilized plates.

Ten grams of representative minced beef patty samples were mixed with $90 \mathrm{~mL}$ peptone in $250 \mathrm{~mL}$ flask under aseptic conditions.

The suspension was checked by hand for 5 min to give 1/10 dilution. Serial dilutions were prepared to be used for counting bacteria.

\section{Total plate count (T.P.C)}

One $\mathrm{ml}$ from each prepared dilution was plated on the above medium in triplicate and incubated at $37^{\circ} \mathrm{C}$ for $48 \mathrm{hr}$. The count was then calculated and expressed as colonies per gram flesh.

\section{Sensory evaluation of beef patties}

The sensory attributes (appearance, odor, texture, taste tenderness and overallacceptability) of the freshly cooked beef patties samples were evaluated using a10point numerical scale; where ten corresponded to "the highest quality", a score less than 4 indicate that the sample is "rejected" (Watts $e t$ al., 1989).

\section{Met-myoglobin content}

Met-myoglobin percentages of the tested samples were estimated according to the method of Trout (1990).

\section{Color measurements}

Color of each tested beef patty sample was measured using a Hunter Lab. scan XE colorimeter (Hunter Lab. Inc., Reston, VA, USA) calibrated with a white standard tile: (X $=77.26, \quad \mathrm{Y}=81.94$ and $\mathrm{Z}=88.14$ ). Commission International d'Eclairage (CIE): $\mathrm{L}^{*}$ (lightness), $\mathrm{a}^{*}$ (redness) and $\mathrm{b}^{*}$ (yellowness) saturation index were measured. Reflectance measurements were collected at $10 \mathrm{~nm}$ increments using illuminate A (Podolak et al., 1997) and three random readings per sample were recorded.

\section{pH value}

Each minced beef patty sample $(10 \mathrm{~g})$ was blended with distilled water $(100 \mathrm{ml})$ for 1 $\min$. The $\mathrm{pH}$ values were measured using a standardized electrode attached to a digital $\mathrm{pH}$ meter (Cyber scan $500 \mathrm{pH}$ meter -Serial No 112598).

\section{Water and oil holding capacities}

Water and Oil holding capacities of lemon peel was determined as described by Chau and Huang, (2003). One gram of powdered sample was weighed, added into $10 \mathrm{~mL}$ of distilled water or $10 \mathrm{~mL}$ of sunflower oil and stirred for $1 \mathrm{~min}$. The suspensions were then centrifuged at $2200 \mathrm{~g}$ for $30 \mathrm{~min}$, and the supernatant volume was measured. WHC or $\mathrm{OHC}$ was expressed as gram of water or oil held per gram of sample.

\section{Statistical analysis}

All measurements were carried out in triplicate and the data were presented as mean 
\pm SD. The effects of adding lemon peel and storage period were analyzed and the data obtained was subjected to one-way analysis of variance (ANOVA) and least significant differences (LSD) at $P<0.05$ were calculated using PC-Stat Version IA procedures (PC-Stat 1985)

\section{Results and Discussion}

\section{Thiobarbituric acid reactive substances (TBARS)}

TBARS method has been used to determine the degree of lipid oxidation (Klangpetch et al., 2016) ${ }^{1}$ also used as an index of lipid oxidation in meat products during storage (Fernández-López et al., 1997 and Pearson, 1991).

Data in Table (2) showed the changes in TBARS values of the prepared raw ground beef patties mixed with lemon peel powder (1\% or $2 \%$ LP samples) during refrigerated storage for 12 days at $4 \pm 1^{\circ} \mathrm{C}$. The results indicated that TBARS values increased over the storage time for all patty samples. Control raw patties sample exhibited significantly higher TBARS values during refrigerated storage period as compared to the other tested lemon peel patties. These LP patties samples showed good quality with lower TBARS till 9 days at $4^{\circ} \mathrm{C}$ as indicated by their lower TBARS (i.e. less than $0.9 \mathrm{mg} \mathrm{MDA} \mathrm{kg}^{-1}$ meat) according to the (ES 1694/2005) ${ }^{4}$ for meat products, whereas opposed to only the nine and twelve days for control samples were up to $1.20 \& 1.45$ respectively. Worthy to note that the tested beef patty with $2 \%$ LP samples showed good quality till the end of refrigerated storage (12days) under the same conditions. The obtained results of the present study agreed the findings of Klangpetch et al., $(2016)^{1}$ who reported that TBARS values increased considerably in control $(2.5 \mathrm{mg}$ $\mathrm{MDA} / \mathrm{kg}$ sample) but remained relatively low in lime peel-treated samples with no significant differences at all concentration (1.5 $-1.8 \mathrm{mg} \mathrm{MDA} / \mathrm{kg}$ sample) and at the end of storage (14 days) and lime peel (Citrus aurantifolia Swingle) reduced the lipid oxidation for more than $40 \%$. However, the accumulation of malonaldehyde (MDA) in patties during refrigerated storage could be due to hydrolytic and oxidative processes in the lipid fraction (Brake and Fennema 1999) ${ }^{5}$.

\section{Total volatile basic nitrogen (TVBN)}

TVBN is a biochemical method for assessing meat spoilage (Pearson, 1991). TVBN changes of beef patties sample are illustrated in (Table 3). At zero day of storage control, $1 \%$ and $2 \%$ LP samples exhibited $10.80,10.50$ and $10.30 \mathrm{mg} \mathrm{N} / 100 \mathrm{~g}$ sample; respectively. These values are an indication of good quality raw material used in this assay and they are similar to some reported previous results by EL-Desouky et al., (2006) and Moawad et al., (2000). Also it is noted that, TVBN of all patty samples gradually increased with different rates depending on addition amount and storage time.

At the end of storage, TVBN reached 25.04, 19.34, and $15.40 \mathrm{mg} \mathrm{N} / 100 \mathrm{~g}$ for control, $1 \%$ and $2 \%$ LP samples respectively. This increase in TVBN values is related to the activity of spoilage bacteria and endogenous enzymes (Pearson, 1991). The lower TVBN values with $1 \%$ or $2 \%$ LP may be due to the effectiveness of the bioactive compound in this citrus peel on microorganisms. Concerning TVBN values as a spoilage index for meat product; (ES 1694/2005) reported that a level above $20 \mathrm{mg} \mathrm{N} / 100 \mathrm{~g}$ sample is usually considered spoiled minced meat. In the present study control beef patties seemed acceptable with TVBN index of storage and its level reached to $20.36 \mathrm{mg} \mathrm{N} / 100 \mathrm{~g}$ sample at $9^{\text {th }}$ day. While, the TVBN of beef patties samples with lemon peels powder was lower 
than the control sample during storage period and reached up to 12 days under the same conditions. These results confirmed the findings of Mexis et al., (2012).

\section{Antioxidant activity (AOA)}

The total antioxidant activity has been generally recognized as a tool to test the antioxidant potential of a pure compound or a food extract (Aruoma 1996). The AOA of a food could be a useful index to predict oxidative stability (Sacchetti et al., 2008).

Data on the antioxidant potential or activity (AOA) of lemon peel as antioxidants in the patty samples stored at $4{ }^{\circ} \mathrm{C}$ for 12 days are depicted in Table 4. A significant difference between the AOA \% of the tested patty samples as a result of adding 1 or $2 \%$ LP during storage was observed. It was noticed that beef patty samples treated with $2 \%$ LP exhibited a higher AOA\% than that treated with $1 \%$ LP during the refrigerated storage. This pattern difference may be due to the phenolic content in 2\%LP samples which exhibited a higher AOA\% than other patty samples treated with $1 \%$ LP.

The data indicated that the antioxidant activity of $1 \& 2 \%$ LP samples may be due to the result of their radical scavenging activity whereas may act in a similar trend as reductions by donating electrons and reacting with free radicals to convert them to more stable products and terminate free radical chain reactions as reported by Negi and Jayaprakasha, 2003.

\section{Radical scavenging activity (DPPH)}

The DPPH was used as a free radical to evaluate antioxidant activity present in natural sources (Schwarz et al., 2001) the use of antibiotics as feed additives has been gradually restricted. Data in Table (5) showed that patties samples with $2 \%$ LP gave the greatest DPPH followed by $1 \%$ LP compared to control at zero time. The DPPH \% activity decreased during refrigerated storage in all patties samples.

Sherwin, (1998) reported that antioxidants are believed to intercept the free radical chain of oxidation and to give hydrogen from the phenolic hydroxyl groups, thereby; forming a stable end product that does not initiate or propagate further oxidation of lipids.

\section{Microbiological properties}

The shelf-life of meat is usually limited by microbial spoilage. Depending on hygiene and preservation conditions, raw beef patties stored aerobically have a shelf-life of around 7-8 days in refrigerated conditions (Sallam and Samejima 2004; Hayes et al., 2010).

In the present study total plate counts (TPC) of beef patties were evaluated and the counts (as $\log 10 \mathrm{CFU} / \mathrm{gm}$ ) are presented in Table (6). Slight higher in TPC value was noticed in control beef patty samples as compared with other treated samples at zero time of cold storage; which can indicate that lemon peel caused sudden lethal effect for microorganisms. As might be expected, increase in storage time produced significant greatly increase in TPC whatever the treatment conditions, thus the storage time have a significant effect on TPCs of raw beef patties (Table 6), whereas by the day 9 of storage TPC value of control sample (7.77 $\log 10 \mathrm{CFU} / \mathrm{gm})$ exceeded the maximal recommended limit of $7 \log 10 \mathrm{CFU} / \mathrm{gm}$ for TPC in raw meat (ICMSF, 1986) indicating a shelf life of about 8 days. Meanwhile, $1 \%$ lemone peel (LP) treatments significantly delayed the microbial growth and extended the shelf life of the product up to 12 days at which the TPC was 5.66 versus $8.88 \log 10 \mathrm{CFU} / \mathrm{gm}$ in control samples. Also it was revealed that at the $12^{\text {th }}$ day of storage samples containing $2 \%$ LP had the lower TPC value (4.75 $\log 10$ 
CFU/gm) than the maximal recommended limit, while control samples exhibited 8.88 $\log 10 \mathrm{CFU} / \mathrm{gm}$, these indicating that as the concentration of LP increased in the formula; the TPC of the samples of LP increased in the formula; the TPC of the samples decreased. Similar results were achieved by (Alahakoon et al., (2013) ${ }^{18}$ who found that significant effects of addition citrus peel extract and onion peel extract to chicken breast meat sample on microbial growth inhibition during storage at different temperatures. Klangpetch et al., (2016) reported also that total viable count (TVC) of all samples increased during storage. Lime peel reduced TVC soon after dipping, to be lower than control and water for 2 and $1.2 \log$-orders during 6 to 10 days of storage.

\section{Water and oil holding capacities}

Water-holding capacity(WHC) is one of the properties of fresh meat as it affects some major characteristics such as potential drip loss, technological quality, appearance and sensory properties (Das et al., 2011). WHC of meat is an important factor affects tenderness, thawing drip and cooking loss of meat (Hamm, 1986). Also it is one of important measurements of quality attributes for possibility of using meat in manufacturing of any meat product. This property is largely affected by the muscles proteins and $\mathrm{pH}$ value level. Generally WHC decline continuously with the progression of storage period.

Oil-holding capacity (OHC) is a technological property related to the chemical structure of the plant polysaccharides and depends on surface properties, overall charge density, thickness, and hydrophobic nature of the fiber particle (Fernandez-Lopez et al., 2009 and Figuerola et al., 2005). Effect of adding lemon peels powder on WHC and OHC of the tested beef patties are presented in Table (7). The lowest $\mathrm{OHC}$ and WHC values were noticed for control beef patties samples compared to other formulated samples. The $\mathrm{OHC}$ and WHC of the tested pattie samples decreased slightly during storage due to the addition of powdered citrus peel. The $\mathrm{OHC}$ increased in beef patties samples contained $2 \%$ lemon peel followed by $1 \%$ lemon peel compared with the control. Similar trends were found in case WHC of the above meat samples.

Viuda-Martos et al., (2012) reported that WHC is related to the soluble dietary fiber (SDF) content, and high levels of SDF produce a high WHC value. This could be explained by the higher WHC of soluble fibers, such as pectin and gums than cellulosic fibers. So, the higher WHC of LP samples could be due to the chemical structures, which possess a higher WHC than cellulosic fibers in citrus peel. Noticeably, all the tested samples showed decrease WHC during refrigerated beef patties. Such effects could be attributed not only to particle size reduction, but also to the altering of the fiber matrix structure. Kethireddipalli et al., (2002) reported that WHC depends on matrix structure formed by polysaccharide chains which can hold large amounts of water through hydrogen bonds.

Also, Sangnark and Noomhorm, (2003) reported that particle size reduction of dietary fibers has been associated with a lower ability to retain water and a lower oil binding capacity.

\section{Determination of $\mathrm{pH}$ value}

Meat $\mathrm{pH}$ is considered as one of the most important technological properties as it alters pigment and lipid stability. Changes in $\mathrm{pH}$ values in ground beef meat during cold storage at $4 \pm 1^{\circ} \mathrm{C}$ for 12 days are presented in Table (8). $\mathrm{pH}$ value of control sample at zero time of storage was 6.01. 
Table.1 Preparation of the Minced beef patties samples

\begin{tabular}{|c|c|c|}
\hline $\begin{array}{c}\text { Control beef patties } \\
\text { sample }\end{array}$ & $\begin{array}{c}\text { Beef patties samples with } 1 \% \\
\text { lemon peels[LP] }\end{array}$ & $\begin{array}{c}\text { Beef patties samples with } \\
2 \% \text { lemon peels[LP] }\end{array}$ \\
\hline $82 \%$ Beef Lean & $80 \%$ Beef Lean & $78 \%$ Beef Lean \\
\hline $15 \%$ Beef Fat & $15 \%$ Beef Fat & $15 \%$ Beef Fat \\
\hline $3 \%$ Cold water & $\begin{array}{l}\text { 5\% Lemon peel suspension: } \\
(1 \% \text { LP +4\%ColdWater })\end{array}$ & $\begin{array}{c}\text { 7\% Lemon peel suspension: } \\
\text { (2\%LP +5\% Coldwater) }\end{array}$ \\
\hline $100 \%=$ Total weight & $100 \%=$ Total weight & $100 \%=$ Total weight \\
\hline
\end{tabular}

Table.2 Thiobarbituric acid reactive substances (TBARS) of the tested patty samples mixed with 1 or $2 \%$ LP during refrigerated storage.

\begin{tabular}{|c|c|c|c|c|c|}
\hline \multirow{2}{*}{$\begin{array}{c}\text { Beef patty } \\
\text { Samples }\end{array}$} & \multicolumn{5}{|c|}{ Refrigerated Storage $\left(\mathbf{4} \pm \mathbf{1}^{\circ} \mathbf{C}\right)$ per day } \\
\cline { 2 - 6 } & 0 & 3 & 6 & 9 & 12 \\
\hline Control & $0.46 \pm 0.01^{\mathrm{a}}$ & $0.59 \pm 0.01^{\mathrm{a}}$ & $0.80 \pm 0.01^{\mathrm{a}}$ & $1.20 \pm 0.01^{\mathrm{a}}$ & $1.45 \pm 0.01^{\mathrm{a}}$ \\
\hline $1 \% \mathrm{LP}$ & $0.39 \pm 0.02^{\mathrm{b}}$ & $0.51 \pm 0.00^{\mathrm{b}}$ & $0.62 \pm 0.01^{\mathrm{c}}$ & $0.72 \pm 0.01^{\mathrm{c}}$ & $0.90 \pm 0.004^{\mathrm{c}}$ \\
\hline $2 \% \mathrm{LP}$ & $0.35 \pm 0.01^{\mathrm{d}}$ & $0.46 \pm 0.004^{\mathrm{d}}$ & $0.55 \pm 0.001^{\mathrm{e}}$ & $0.61 \pm 0.01^{\mathrm{e}}$ & $0.77 \pm 0.004^{\mathrm{e}}$ \\
\hline
\end{tabular}

All values are mean of triplicate determinations \pm standard deviation (SD). Mean values in the same column $\&$ raw bearing the same superscript do not differ significantly $(\mathrm{P}<0.05)$. Thiobarbituric acid reactive substances (TBARS) as mg of malonaldehyde per Kg sample . LP=Lemon Peel

Table.3 Total volatile basic nitrogen (mg N/100gm sample) changes of the prepared beef patties during refrigerated storage at $4 \pm 1{ }^{\circ} \mathrm{C}$ for 12 days

\begin{tabular}{|c|c|c|c|c|c|}
\hline \multirow{2}{*}{$\begin{array}{c}\text { Beef patty } \\
\text { Samples }\end{array}$} & \multicolumn{5}{|c|}{ Refrigerated Storage $\left(4 \pm 1^{\circ} \mathrm{C}\right)$ per day } \\
\hline & 0 & 3 & 6 & 9 & 12 \\
\hline Control & $10.80^{\mathrm{a}} \pm 0.01$ & $13.27^{\mathrm{a}} \pm 0.01$ & $16.46^{\mathrm{a}} \pm 0.02$ & $20.36^{\mathrm{a}} \pm 0.02$ & $25.04^{\mathrm{a}} \pm 0.04$ \\
\hline $1 \% \mathrm{LP}$ & $10.50^{c} \pm 0.02$ & $11.50^{c} \pm 0.00$ & $12.75^{\mathrm{c}} \pm 0.01$ & $16.07^{\mathrm{c}} \pm 0.04$ & $19.34^{c} \pm 0.03$ \\
\hline $2 \% \mathrm{LP}$ & $10.30^{\mathrm{c}} \pm 0.02$ & $10.40^{\mathrm{e}} \pm 0.01$ & $11.45^{\mathrm{e}} \pm 0.01$ & $13.46^{\mathrm{e}} \pm 0.02$ & $15.40^{\mathrm{e}} \pm 0.02$ \\
\hline
\end{tabular}

All values are mean of triplicate determinations \pm standard deviation (SD). Mean values in the same column bearing the same superscript do not differ significantly $(\mathrm{P}>0.05)$. LP $=$ Lemon Peel

Table.4 Antioxidant activity (AOA \%) of the tested beef patty mixed with $1 \%$ LP and $2 \%$ LP samples during refrigerated storage at $4 \pm 1^{\circ} \mathrm{C}$ per day

\begin{tabular}{|c|c|c|c|c|c|}
\hline \multirow{2}{*}{$\begin{array}{c}\text { Beef patty } \\
\text { Samples }\end{array}$} & \multicolumn{5}{|c|}{ Refrigerated Storage $\left(\mathbf{4} \pm \mathbf{1}^{\circ} \mathbf{C}\right)$ per day } \\
\hline $1 \%$ LP & 15.22 & $\mathbf{3}$ & $\mathbf{6}$ & $\mathbf{9}$ & $\mathbf{1 2}$ \\
\hline $2 \%$ LP & 23.91 & 22.03 & 22.50 & 40.00 & 37.93 \\
\hline
\end{tabular}

All values are mean of triplicate determinations \pm standard deviation (SD). LP= Lemon Peel 
Table.5 Changes radical scavenging activity (DPPH \%) values of beef patty samples during storage at $4 \pm 1{ }^{\circ} \mathrm{C}$ for 12 days

\begin{tabular}{|c|c|c|c|c|c|}
\hline \multirow{2}{*}{$\begin{array}{c}\text { Beef patty } \\
\text { Samples }\end{array}$} & \multicolumn{5}{|c|}{ Refrigerated Storage $\left(4 \pm \mathbf{1}^{\circ} \mathbf{C}\right)$ per day } \\
\cline { 2 - 6 } & $\mathbf{0}$ & $\mathbf{3}$ & $\mathbf{6}$ & $\mathbf{9}$ & $\mathbf{1 2}$ \\
\hline Control & $1.83^{\mathrm{e}} \pm 0.03$ & $0.90^{\mathrm{e}} \pm 0.03$ & $0.08^{\mathrm{e}} \pm 0.03$ & $0.02^{\mathrm{e}} \pm 0.04$ & $0.00^{\mathrm{e}} \pm 0.00$ \\
\hline $1 \%$ LP & $23.61^{\mathrm{c}} \pm 0.03$ & $18.39^{\mathrm{c}} \pm 0.45$ & $13.98^{\mathrm{c}} \pm 0.47$ & $9.80^{\mathrm{c}} \pm 0.07$ & $3.69^{\mathrm{c}} \pm 0.03$ \\
\hline $2 \%$ LP & $34.01^{\mathrm{a}} \pm 0.1$ & $29.03^{\mathrm{a}} \pm 0.2$ & $25.19^{\mathrm{a}} \pm 0.2$ & $21.17^{\mathrm{a}} \pm 0.07$ & $16.38^{\mathrm{a}} \pm 0.1$ \\
\hline
\end{tabular}

All values are mean of triplicate determinations \pm standard deviation (SD). Mean values in the same column bearing the same superscript do not differ significantly $(\mathrm{P}<0.05) . \mathrm{LP}=$ lemon peel

Table.6 Total plate count changes of beef patty samples during refrigerated storage at $4 \pm 1{ }^{\circ} \mathrm{C}$ for 12 days (as $\log 10 \mathrm{CFUgm}^{-1}$ )

\begin{tabular}{|c|c|c|c|c|c|}
\hline Beef patty & \multicolumn{5}{|c|}{ Refrigerated Storage $\left(4^{\circ} \mathbf{C}\right)$ per day } \\
\cline { 3 - 6 } Samples & $\mathbf{0}$ & $\mathbf{3}$ & $\mathbf{6}$ & $\mathbf{9}$ & $\mathbf{1 2}$ \\
\hline Control & $4.97^{\mathrm{a}} \pm 0.04$ & $6.05^{\mathrm{a}} \pm 0.05$ & $7.43^{\mathrm{a}} \pm 0.06$ & $7.77^{\mathrm{a}} \pm 0.15$ & $8.88^{\mathrm{a}} \pm 0.14$ \\
\hline $1 \%$ LP & $3.27^{\mathrm{b}} \pm 0.13$ & $3.48^{\mathrm{b}} \pm 0.11$ & $4.72^{\mathrm{b}} \pm 0.08$ & $5.56^{\mathrm{b}} \pm 0.06$ & $5.66^{\mathrm{b}} \pm 0.05$ \\
\hline $2 \%$ LP & $1.35^{\mathrm{c}} \pm 0.91$ & $2.87^{\mathrm{c}} \pm 0.2$ & $3.39^{\mathrm{c}} \pm 0.17$ & $4.63^{\mathrm{c}} \pm 0.07$ & $4.75^{\mathrm{c}} \pm 0.11$ \\
\hline
\end{tabular}

All values are mean of triplicate determinations \pm standard deviation (SD). Mean values in the same column bearing the same superscript do not differ significantly $(\mathrm{P}<0.05)$. Total plate count as $\log 10 \mathrm{CFUgm}^{-1}$, LP: Lemon Peel.

Table.7 Water and oil holding capacity values changes of beef patties sample during refrigerated storage at $4 \pm 1{ }^{\circ} \mathrm{C}$ for 12 days

\begin{tabular}{|c|c|c|c|c|c|}
\hline \multirow{2}{*}{$\begin{array}{c}\text { Beef patties } \\
\text { Sample }\end{array}$} & \multicolumn{5}{|c|}{ Storage(day) } \\
\cline { 2 - 6 } & $\mathbf{0}$ & $\mathbf{3}$ & $\mathbf{6}$ & $\mathbf{9}$ & $\mathbf{1 2}$ \\
\hline Control & $1.50^{\mathrm{c}} \pm 0.04$ & $1.35^{\mathrm{c}} \pm 0.02$ & $1.11^{\mathrm{c}} \pm 0.10$ & $0.50^{\mathrm{c}} \pm 0.03$ & $0.11^{\mathrm{e}} \pm 0.01$ \\
\hline $1 \%$ LP & $3.87^{\mathrm{b}} \pm 0.03$ & $3.74^{\mathrm{b}} \pm 0.02$ & $3.59^{\mathrm{b}} \pm 0.02$ & $3.13^{\mathrm{b}} \pm 0.10$ & $2.94^{\mathrm{c}} \pm 0.02$ \\
\hline $2 \%$ LP & $4.04^{\mathrm{a}} \pm 0.11$ & $3.90^{\mathrm{a}} \pm 0.03$ & $3.77^{\mathrm{a}} \pm 0.01$ & $3.47^{\mathrm{a}} \pm 0.04$ & $3.29^{\mathrm{a}} \pm 0.02$ \\
\hline \multicolumn{7}{|c|}{ Oil Holding Capacity } \\
\hline Control & $0.70^{\mathrm{c}} \pm 0.02$ & $0.60^{\mathrm{c}} \pm 0.03$ & $0.42^{\mathrm{c}} \pm 0.01$ & $0.18^{\mathrm{e}} \pm 0.02$ & $0.05^{\mathrm{e}} \pm 0.00$ \\
\hline $1 \%$ LP & $1.07^{\mathrm{b}} \pm 0.04$ & $0.92^{\mathrm{b}} \pm 0.01$ & $0.91^{\mathrm{c}} \pm 0.01$ & $0.78^{\mathrm{c}} \pm 0.01$ & $0.69^{\mathrm{c}} \pm 0.03$ \\
\hline $2 \%$ Lp & $1.59^{\mathrm{a}} \pm 0.03$ & $1.51^{\mathrm{a}} \pm 0.04$ & $1.47^{\mathrm{a}} \pm 0.04$ & $1.37^{\mathrm{a}} \pm 0.06$ & $1.28^{\mathrm{a}} \pm 0.04$ \\
\hline
\end{tabular}

All values are mean of triplicate determinations \pm standard deviation (SD). Mean values in the same column bearing the same superscript do not differ significantly $(\mathrm{P}>0.05)$ and $\mathrm{LP}=$ Lemon Peel

Table. $8 \mathrm{pH}$ changes of beef patties during refrigerated storageat $4 \pm 1^{\circ}$ for 12 days

\begin{tabular}{|c|c|c|c|c|c|}
\hline \multirow{2}{*}{$\begin{array}{c}\text { Beef patties } \\
\text { Sample }\end{array}$} & \multicolumn{5}{|c|}{ Refrigerated Storage (day) } \\
\cline { 2 - 6 } & $\mathbf{0}$ & $\mathbf{3}$ & $\mathbf{6}$ & $\mathbf{9}$ & $\mathbf{1 2}$ \\
\hline Control & $6.01^{\mathrm{a}} \pm 0.01$ & $6.20^{\mathrm{a}} \pm 0.00$ & $6.33^{\mathrm{a}} \pm 0.00$ & $7.31^{\mathrm{a}} \pm 0.01$ & $7.82^{\mathrm{a}} \pm 0.00$ \\
\hline $1 \%$ LP & $5.80^{\mathrm{bc}} \pm 0.01$ & $5.95^{\mathrm{bc}} \pm 0.00$ & $6.03^{\mathrm{c}} \pm 0.00$ & $6.30^{\mathrm{b}} \pm 0.00$ & $6.58^{\mathrm{c}} \pm 0.00$ \\
\hline $2 \%$ LP & $5.71^{\mathrm{c}} \pm 0.01$ & $5.85^{\mathrm{d}} \pm 0.00$ & $5.97^{\mathrm{c}} \pm 0.00$ & $6.22^{\mathrm{c}} \pm 0.01$ & $6.37^{\mathrm{a}} \pm 0.00$ \\
\hline
\end{tabular}

All values are mean of triplicate determinations \pm standard deviation (SD). Mean values in the same column bearing the same superscript do not differ significantly $(\mathrm{P}>0.05)$. LP= Lemon Peel 
Table.9 Instrumental color values of beef patties as affected by addition of lemon peel powder during refrigerated storage at $4 \pm 1{ }^{\circ} \mathrm{C}$ for 12 days

\begin{tabular}{|c|c|c|c|c|c|c|}
\hline \multirow{2}{*}{$\begin{array}{c}\text { Beef patties } \\
\text { Samples }\end{array}$} & \multicolumn{6}{|c|}{ Refrigerated Storage (day) } \\
\hline & Parameter & $\mathbf{0}$ & 3 & 6 & 9 & 12 \\
\hline \multirow[t]{3}{*}{ Control } & $L^{*}$ & $52.07 \pm 0.02$ & $53.88 \pm 0.04$ & $56.03 \pm 0.01$ & $56.75 \pm 0.02$ & $56.96 \pm 0.04$ \\
\hline & $a^{*}$ & $9.11 \pm 0.01$ & $7.72 \pm 0.02$ & $6.41 \pm 0.03$ & $6.33 \pm 0.03$ & $6.02 \pm 0.01$ \\
\hline & $b^{*}$ & $18.69 \pm 0.11$ & $17.31 \pm 0.01$ & $16.91 \pm 0.02$ & $16.68 \pm 0.03$ & $16.03 \pm 0.02$ \\
\hline \multirow{3}{*}{$1 \% \mathrm{LP}$} & $L^{*}$ & $58.35 \pm 0.01$ & $58.57 \pm 0.01$ & $59.37 \pm 0.01$ & $59.78 \pm 0.03$ & $59.91+0.07$ \\
\hline & $a^{*}$ & $11.16 \pm 0.05$ & $9.11 \pm 0.05$ & $8.46 \pm 0.06$ & $8.37 \pm 0.04$ & $8.14 \pm 0.03$ \\
\hline & $b^{*}$ & $19.3 \pm 0.03$ & $17.47 \pm 0.0$ & $17.31 \pm 0.01$ & $17.27 \pm 0.03$ & $17.03 \pm 0.06$ \\
\hline & & & & & & \\
\hline \multirow[t]{3}{*}{$2 \% \mathrm{LP}$} & $L^{*}$ & $59.30 \pm 0.01$ & $58.61 \pm 0.05$ & $63.07 \pm 0.04$ & $63.26 \pm 0.04$ & $63.34 \pm 0.02$ \\
\hline & $a^{*}$ & $13.27 \pm 0.03$ & $9.72 \pm 0.03$ & $9.09 \pm 0.05$ & $8.96 \pm 0.03$ & $8.73 \pm 0.02$ \\
\hline & $b^{*}$ & $20.78 \pm 0.0$ & $18.68 \pm 0.02$ & $18.21 \pm 0.06$ & $18.05 \pm 0.05$ & $17.89 \pm 0.02$ \\
\hline
\end{tabular}

All values are mean of triplicate determinations \pm standard deviation (SD). Mean values in the same column bearing the same superscript do not differ significantly $(\mathrm{P} \leq 0.05) \mathrm{LP}=$ Lemon Peel

Table.10 Met-myoglobin $\%$ of beef patties as affected by addition of lemon peel powder during refrigerated storage at $4 \pm 1{ }^{\circ} \mathrm{C}$ for 12 days

\begin{tabular}{|c|c|c|c|c|c|}
\hline Beef patties & \multicolumn{5}{|c|}{ Refrigerated Storage $\left(\mathbf{4} \pm \mathbf{1}^{\circ} \mathbf{C}\right)$ per day } \\
\cline { 2 - 6 } Samples & $\mathbf{0}$ & $\mathbf{3}$ & $\mathbf{6}$ & $\mathbf{9}$ & $\mathbf{1 2}$ \\
\hline Control & 19.20 & 38.00 & 53.11 & 70.09 & 76.47 \\
\hline $1 \%$ LP & 18.83 & 33.05 & 41.01. & 43.19 & 47.42 \\
\hline $2 \%$ LP & 18.75 & $\mathbf{3 1 . 3 3}$ & 33.32 & 37.45 & 40.74 \\
\hline
\end{tabular}

Table.11 Sensory evaluation of the beef patties containing powder of lemon peels during refrigerated storage at $4 \pm 1{ }^{\circ} \mathrm{C}$

\begin{tabular}{|c|c|c|c|c|c|c|c|}
\hline $\begin{array}{c}\text { Beef patty } \\
\text { Samples }\end{array}$ & Color & Appearance & Odor & Texture & Taste & Tenderness & $\begin{array}{c}\text { Overall- } \\
\text { Acceptability }\end{array}$ \\
\hline \multicolumn{7}{|c|}{ Zero time } \\
\hline Control & $7.56^{\mathrm{e}} \pm 1.5$ & $7.19^{\mathrm{d}} \pm 1.76$ & $7.25^{\mathrm{c}} \pm 1.39$ & $7.31^{\mathrm{c}} \pm 1.40$ & $7.19^{\mathrm{c}} \pm 1.63$ & $7.13^{\mathrm{e}} \pm 1.63$ & $7.15^{\mathrm{d}} \pm 0.55$ \\
\hline $1 \%$ LP & $7.69^{\mathrm{d}} \pm 0.10$ & $7.69^{\mathrm{c}} \pm 0.95$ & $7.44^{\mathrm{b}} \pm 1.05$ & $7.13^{\mathrm{d}} \pm 1.36$ & $7.06^{\mathrm{d}} \pm 1.61$ & $7.56^{\mathrm{d}} \pm 1.21$ & $7.54^{\mathrm{c}} \pm 0.78$ \\
\hline $2 \%$ IP & $8.50^{\mathrm{a}} \pm 1.21$ & $8.19^{\mathrm{a}} \pm 1.47$ & $8.13^{\mathrm{a}} \pm 1.41$ & $7.81^{\mathrm{a}} \pm 1.17$ & $8.38^{\mathrm{a}} \pm 1.20$ & $8.19^{\mathrm{a}} \pm 1.11$ & $8.38^{\mathrm{a}} \pm 0.77$ \\
\hline \multicolumn{7}{|c|}{ The third day } \\
\hline Control & $7.00^{\mathrm{e}} \pm 1.00$ & $7.23^{\mathrm{e}} \pm 1.00$ & $6.92^{\mathrm{c}} \pm 0.95$ & $6.77^{\mathrm{e}} \pm 1.79$ & $6.85^{\mathrm{c}} \pm 1.34$ & $6.77^{\mathrm{d}} \pm 1.42$ & $6.17^{\mathrm{e}} \pm 0.58$ \\
\hline $1 \%$ LP & $7.46^{\mathrm{c}} \pm 0.78$ & $7.54^{\mathrm{c}} \pm 1.05$ & $6.92^{\mathrm{c}} \pm 1.19$ & $7.69^{\mathrm{c}} \pm 0.75$ & $6.69^{\mathrm{d}} \pm 1.38$ & $7.38^{\mathrm{b}} \pm 1.39$ & $7.54^{\mathrm{c}} \pm 0.78$ \\
\hline $2 \%$ LP & $8.31^{\mathrm{a}} \pm 1.03$ & $8.31^{\mathrm{a}} \pm 0.85$ & $8.15^{\mathrm{a}} \pm 0.80$ & $8.00^{\mathrm{a}} \pm 1.08$ & $7.77^{\mathrm{b}} \pm 1.17$ & $8.08^{\mathrm{a}} \pm 0.64$ & $8.38^{\mathrm{a}} \pm 0.77$ \\
\hline \multicolumn{7}{|c|}{ The sixth day } \\
\hline Control & $5.75^{\mathrm{e}} \pm 1.66$ & $6.17^{\mathrm{e}} \pm 1.47$ & $5.83^{\mathrm{e}} \pm 1.34$ & $5.83^{\mathrm{e}} \pm 1.59$ & $5.50^{\mathrm{d}} \pm 1.57$ & $5.67^{\mathrm{e}} \pm 1.50$ & $6.17^{\mathrm{e}} \pm 0.58$ \\
\hline $1 \%$ LP & $7.21^{\mathrm{c}} \pm 1.34$ & $7.58^{\mathrm{c}} \pm 0.51$ & $7.00^{\mathrm{c}} \pm 1.21$ & $7.58^{\mathrm{c}} \pm 0.79$ & $7.00^{\mathrm{c}} \pm 1.04$ & $7.50^{\mathrm{c}} \pm 1.17$ & $7.50^{\mathrm{c}} \pm 0.48$ \\
\hline $2 \%$ IP & $8.25^{\mathrm{a}} \pm 1.08$ & $8.58^{\mathrm{a}} \pm 0.51$ & $8.17^{\mathrm{a}} \pm 0.72$ & $8.17^{\mathrm{a}} \pm 0.72$ & $7.42^{\mathrm{b}} \pm 1.24$ & $8.17^{\mathrm{a}} \pm 0.72$ & $8.58^{\mathrm{a}} \pm 0.47$ \\
\hline
\end{tabular}

All values are mean of eleven repeated determinations \pm standard deviation (SD). Mean values in the same column bearing the same superscript do not differ significantly $(\mathrm{P}>0.05) \mathrm{LP}=$ Lemon peel 
The $\mathrm{pH}$ values of raw samples (mixed with 1 or $2 \%$ LP) obviously decreased to be less than 6.00 (slight acidic values). This decrease in $\mathrm{pH}$ values could be due to the presence of some organic acids found in LP which shifted the control sample to be less slightly acidic.

Braddock, (1995) reported that the $\mathrm{pH}$ values of samples with added lemon albedo were lower than control samples. This decrease in $\mathrm{pH}$ could be related to the presence of some organic acid in albedo. Generally, it was shown the $\mathrm{pH}$ value increased gradually with increasing storage time (Table 8). Abd El-Aal (2005) and Das et al.,(2011) also reported that an increase in $\mathrm{pH}$ during the storage period may be due to growth of Gram-negative bacteria and due to accumulation of metabolites by bacterial action on protein and amino acids.

Instrumental color measurement due to the concentration of myoglobin, hemoglobin and their chemical Color is an important factor which observed by consumers to indicate meat freshness and healthiness in order to purchase. The color of meat is caused states (Brewer, 2004) Instrumental color evaluation (Table 9) in the present is study revealed a significant $(\mathrm{P} \leq 0.05)$ effect of 1 or $2 \%$ of lemon peel powder on Hunter color parameters values of the formulated beef patties samples.

Color $\left(\mathrm{L}^{*}\right)$ values of the control sample was increased all over the storage period and the reverse pattern occurred for $\mathrm{a}^{*}$ (redness) and $b^{*}$ (Yellowness) color values. Mixing of LP affected all color values relative to the control. Addition of lemon peel to the tested patties sample ( $1 \%$ or $2 \%$ LP) affected the color parameters values during the storage period. Lightness $\left(\mathrm{L}^{*}\right)$ values was increased to reach $(59.91 \& 63.34)$ respectively, at the $12^{\text {th }}$ day (end of storage). Meanwhile, a*(redness) values decreased compared to control along the storage period to be $(8.14 \& 8.73)$ respecively. Also, the $b^{*}$ (Yellowness) were of lower values than the control to be $(17.03 \&$ 17.89) at the end of storage period. A decrease in $\left(b^{*}\right)$ and $\left(a^{*}\right)$ values of beef patties containing natural antioxidants has been reported by Ashour et al., (2014) who reported that over storage time, the $a^{*}$ values of all patties sample decreased and becoming less red or brown due to met-myoglobin. The yellowness $\left(b^{*}\right)$ values followed similar trend decreasing to day 12. Also, Rojas and Brewer, (2008) reported a decrease in $\left(b^{*}\right)$ values of beef patties containing natural antioxidants. Aleson-Carbonell et al., 2005 cleared that addition of any type of citrus albedo at any concentration increased surface $b^{*}$ and $a^{*}$ values. This increase in $b^{*}$ value is related to the incorporation of yellowness and redness components present in albedo to a studied burgers.

\section{Met-myglopin Content}

The oxidative changes are more intense in minced meat due to increased surface area and exposure to air during grinding and processing than intact meat. Das et al., (2006) cleared that ground buffalo meat tends to become brown and rancid more rapidly than whole retail cuts. Trout (1990) the meat color varies depending on the state of myoglobin. Myoglobin has three natural colors depending on its exposure to oxygen and the chemical state of the iron. If no oxygen is present, the meat appears purple red, and it is in the deoxy-myoglobin state. Bright red color indicates oxymyoglobin is present. Meat appears tan or brown when only very small amounts of oxygen are present.

Met-myoglobin is the state when the iron has oxidized and is tan or brown in color. Metmyoglobin is responsible for the undesirable brown color of fresh meat. Meat can also appear brown when the meat color life is exhausted late in display when the iron in the pigment becomes oxidized. Although 
brownish-red colored meat can indicate spoilage, it doesn't always mean that meat meat is spoiled.

In the present investigation, effect of adding Lemon peel on met-myoglobin \% of raw ground meat was studied and compared with control beef meat patty over 12 days of refrigerated storage (Table10). Generally, the present investigation indicated that metmyoglobin percentages of the control beef meat patties (LP samples) were higher than those of the tested samples with Lemon Peel (1\% LP and 2\% LP samples) during the refrigerated storage period (Table 10). Also, it was noticed when the refrigerated storage period increased, met-myoglobin accumulation in all the meat samples increased consistently. The control sample revealed the highest met-myoglobin\% estimated from $19.20 \%$ at the zero day of storage to $76.47 \%$ at the end of the storage period. Noticeably, Sahoo and Anjaneyulu (1997) also reported that highly significant effects of the storage period by increasing met-myoglobin in ground buffalo meat were observed.

In the present study beef patties samples mixed with $2 \%$ LP gave lowest percentage of Met-myoglobin that $(40.74 \%)$ at the end of storage period(12days). Meanwhile beef patty samples (1\% LP sample) exhibited Metmyoglobin percentage $47.42 \%$ at the end of storage time

\section{Sensory evaluation}

The results of the sensory evaluation are presented in Table (11). Beef patties incorporating 1 or $2 \%$ lemon peel powder were of high sensory attributes than control sample at zero time. Meanwhile, the sensory attributes were increased by increasing the storage time. At $3^{\text {rd }}$ day of storage, of the LP patty samples were noticed to be more than the sensory attributes corresponding $1 \%$ formulations. Also, at $6^{\text {th }}$ day of storage $2 \%$ LP samples were more acceptable than the corresponding $1 \%$ samples. Regarding the overall-acceptability of the studied samples it was found that at zero day of storage the control sample was (7.69), this overallacceptability increased gradually for the formulated samples. At $3^{\text {rd }}$ day of storage the overall-acceptability of the control sample decreased relative to its corresponding at zero days. Worthy to note that the $2 \%$ LP formulated patty samples were more accepted than $1 \%$ LP samples; also 2\% LP sample was of more acceptable sample.

At six days of storage the overall-acceptability of the control sample was of lowest acceptability (6.17), this acceptability increased for the formulated samples but still the 2\% LP samples having great acceptability followed with $1 \%$ corresponding samples. Thus, it can be concluded that overall acceptability scores of the formulated samples increased with the increasing levels of citrus peel.

From the present investigation it was concluded that adding Lemon peel powder to minced beef patties could inhibit oxidation changes, retard development of rancidity and discoloration, enhance color quality and minimize, as possible, met-myoglobin formation in meat during the applied storage period. Samples of $2 \%$ LP gained the great acceptability more than the $1 \%$ samples.

Also, overall acceptability scores of the formulated samples increased with increasing levels of citrus peel. Thus, samples of the suggested $1 \%$ or $2 \%$ Lemon peel powdered could be employed as cheap food additives and used as a substitute for synthetic antioxidants for enhancing the shelf life of minced beef meat patties. Also, can be used as functional ingredients when designing healthy meat products 


\section{References}

Aleson-Carbonell, L.; Ferna'ndez-Lo'pez, J.; Sayas-Barbera', E.; Sendra, E. and Pe'rez-Alvarez, J. A. (2003). Utilization of lemon albedo in dry-cured sausages. Journal of Food Science, 68: 18261830.

Aleson-Carbonell, L.; Ferna'ndez-Lo'pez, J.; Sendra, E.; Sayas-Barbera', M. E. and Pe'rez-Alvarez, J. A. (2004). Quality characteristics of a non-fermented drycured sausage formulated with lemon albedo. Journal of the Science of Food and Agricultural, 84: 2077-2084.

Aleson-Carbonell, L.; Fernandez-Lopez, J.; Perez-Alvarez, J. A. and Kuri, V. (2005). "Functional and sensory effects of fibre-rich ingredients on breakfast fresh sausages", Food Science and Technology International, 11(2): 89-97.

APHA, (2001).American Public Health Association (2001). Compendium of methods for the microbiological examination of foods. Downes FP, Ito K, Eds. American Public Health Association: Washington, DC: USA; 4th Edt..

Ayala-Zavala, J. F.; Vega-Vega, V.; RosasDomínguez, C.; Palafox-Carlos, H.; Villa- Rodríguez, J.A.; Siddiqui, M.W.; Dávila-Aviña, J.E. and GonzálezAguilar, G.A. (2011). Agro-industrial potential of exotic fruit byproducts as a source of food ad- ditives. Food Res. Int., 44(7): 1866-1874.

Brake, N. C. and Fennema, O. R. (1999). Lipolysis and lipid oxidation in frozen minced mackerel as related to $\mathrm{Tg}$, molecular diffusion and presence of gelatin. J. Food Sci., 64(1): 25-32.

Brewer, M. S. (2011). Natural antioxidants: Sources, compounds, mechanisms of action, and potential applications. Compr. Rev. Food Sci. Food Saf., 10: 221-247.
Camo et al., 2008: Extension of the display life of lamb with an antioxidant active packaging

Chau, C. F.; Huang, Y. L. and Lee, M. H. (2003). In vitro hypoglycaemic effects of different insoluble fibre-rich fractions prepared from the peel of Citrus Sinensis L.cv. Liucheng. Journal of Agricultural and Food Chemistry, 6623-6626.

Das, A. K.; Rajkumar, V. and Dwivedi, D. K. (2011). Antioxidant effect of curry leaf (Murraya koenigii) powder on quality of ground and cooked goat meat. International Food Research Journal, 18: 563-569.

Difco-Manual. (1998). Culture Media and Ingredients, Dehydrated 11th Ed. Pub. Difco Lab., Division of Becton Dickimson and Company. Sparks, Maryland, USA.

Djamel Djenane Food Chemistry 76 (2002) 407-415, Antioxidant effect of carnosine and carnitine in fresh beef steaks stored under modified atmosphere, Armida Sánchez Escalante1, José A. Beltrán, Pedro Roncale's

Djamel Djenane , Armida Sa' nchez Escalante1, Jose'A. Beltrán, Pedro (Food Chemistry 76 (2002) 407-415, Antioxidant effect of carnosine and carnitine in fresh beef steaks stored under modified atmosphere Roncale's ) Ability of $\alpha$-tocopherol, taurine and rosemary, in combination with vitamin $\mathrm{C}$, to increase the oxidative stability of beef steaks packaged in modified atmosphere, Food Chemistry Volume 76, Issue 4, April 2002, Pages 407-415

Djamel Djenane , Armida Sa nchez Escalante1, JoséA. Beltrán, Pedro Roncale's*a Department of Animal Production and Food Science, Laboratory of Food Technology, Faculty of Veterinary Science, 
University of Zaragoza, C/Miguel Servet, 177, 50013, Zaragoza, Spain Received 3 January 2001; received in revised form 24 July 2001; accepted 27 July 2001.

Djamel Djenane, Luis Martı'nez, Armida Sa'nchez-Escalante1Jose' A. Beltra'n, Pedro Roncale's, Antioxidant effect of carnosine and carnitine in fresh beef steaks stored under modified atmosphere, Food Chemistry 85 (2004) 453-459, Food Chemistry 3rd Ed O, Anton, M, Gatellier, P., and Renerre, M. 1993. Microsomal lipid peroxidation in relation with oxidation of bovine myoglobin. Proc. 37th ICoMST, Kulmbach, pp.320-323.

Djenane, D. (2015). Chemical Profile, Antibacterial and Antioxidant Activity of Algerian Citrus Essential Oils and Their Application in Sardina pilchardus. Foods, 4: 208-228. doi:10.3390/foods 402020

Effect of some essential oils and preservatives on the growth of E. coli o157 and quality of refrigerate minced meat. Annals of Agricultural Sciences, Moshtohor, 44(4):1675-1695.

EL-Desouky, A. I.; Bahlol, H. E. M. and Sharoba, A. M. A. (2006).

ES, (1694/2005): Egyptian standards for minced meat. Egyptian Organization for Standardization and Quality Control. Ministry of Industry. Cairo, Egypt

Estivez 2995 Oxidation of lipids and proteins in frankfurters with different fatty acid compositions and tocopherol and phenolic contents, Food Chemistry100, Issue 1, 2005, Pages 55-63

Fennema 9ed) (Marcel Dekker., Book,1996, May 1, 2014. Food Chemistry 3rd Ed O Fennema 9ed) (Marcel Dekker, (1996) WW Pdf. Version, [version]. Download, 5721. Stock, [quota]. Total Files, 1. File

Fernández-López, J.; Pérez-Alvarez, J. A. and
Fernández-López, J. A. (1997). Thiobarbituric acid test for monitoring lipid oxidation in meat. Food Chem., 59:345-353

Fernandez-Lopez, J.; Sendra-Nadal, E.; Navarro, C.; Sayas, E.; Viuda-Martos, M. and Perez-Alvarez, J. A. (2009). Storage stability of a high dietary fibre powder from orange by-products. International Journal of Food Science and Technology, 44(4): 748-756.

Fernandez-Lopez, J.; Zhi, N.; AlesonCarbonell, L.; Perez- Alvarez, J. A. and Kuri, V. (2005). "Antioxidant and antibacterial activities of natural extracts: Application on cooked meat balls", Meat Science, 69: 371-380.

Frankel 2008 Mechanism of Lipid Peroxidation in Meat and Meat Products -A Review, Food Sci. Biotechnol. Vol. 14, No. 1, pp. 152 163 (1998)

Frazier,W. C. and Foster, E.M. (1950). Laboratory manual for food microbiology. Burgess publishing Co., Minnesota, U.S.A

Hamm, R. (1986). Functional properties of the myofibrillar system and their measurements, In: Bechtel P. J. (Ed.), Muscle as food, pp. 135-199, Academic Press Inc., New York, USA.

Hayes, J. E.; Stepanyan, V.; Allen, P.; O'Grady, M. N. and Kerry, J. P. (2010). Effect of lutein, sesamol, ellagic acid and olive leaf extract on the quality and shelf-life stability of packaged raw minced beef patties. Meat Science, 84: 613-620.

ICMSF (International Commission on Microbiological Specification for Foods), 1986. Microorganisms in Foods 2. Sampling for microbiological analysis: Principles and specific applications, 2nd Ed. University of Toronto Press, Toronto, Canada.

Javier Camo, José Antonio Beltrán, Pedro 
Roncalés Extension of the display life of lamb with an antioxidant active package Camo J, Beltrán J A, Roncalés P.Meat Sci Dec;80(4):1086-91.doi: 10.1016/j.meatsci.2008.04.031. Epub 2008 May 7.

Kethireddipalli, P.; Hung, Y. C.; Phillips, R. D. and McWatters, K.H. (2002). Evaluating the role of cell material and soluble protein in the functionality of cowpea (Vigna unguiculata) pastes. J. Food Sci., 67: 53-59.

Klangpetch, W.; Phromsurin, K.; Hannarong, K.; Wichaphon, J. and Rungchang, S. (2016). Antibacterial and antioxidant effects of tropical citrus peel extracts to improve the shelf life of raw chicken drumettes. International Food Research Journal, 23(2): 700-707. http://www.ifrj.upm.edu.my

Manthley, J. A. and Grohmann, K. (2001). Phenols in citrus peel byproducts. Concentrations of hydroxycinnamates and polymethoxylated flavones in citrus peel molasses. Journal of Agricultural and Food Chemistry, 49: 3268-3273.

Marı'n, F. R.; Martınez, M.; Uribesalgo, T.; Castillo, S. and Frutos, M. J. (2002). Changes in nutraceutical composition of lemon juices according to different industrial extraction systems. Food Chemistry, 78: 319-324.

Mexis, S. F.; Chouliara, E. and Kontominas, M.G. (2012). Shelf life extension of ground chicken meat using an oxygen absorber and a citrus Extract. LWTFood Science and Technology, 49: 2127.

Michalczyk, M.; Macura, R.; Tesarowicz, I. and Banaś, J. (2012). Effect of adding essential oils of coriander (Coriandrum sativum L.) and hyssop (Hyssopus officinalis L.) on the shelf life of ground beef. Meat Science, 90: 842-850.

Mitsumoto, M.; O'Grady, M. N.; Kerry, J. P. and Buckley, D. J. (2005). Addition of tea catechins and vitamin $\mathrm{C}$ on sensory evaluation, color and lipid stability during chilled storage in cooked or raw beef and chicken patties. Meat Science, 69: 773-779.

Moawad, R. K., Salem, S. A.; Morsi, H. H.; Mohamed, H. S. and El- Magoli, S. B. (2000). Chemical composition, quality attributes of ostrich meat produced in Egypt in comparison to beef and chicken meat. Mansoura J. Agric. Sci., 25 (12):7937-7950.

Negi, P.S., G.K. Jayaprakasha, (2003) Antioxidant and Antibacterial Activities of Punica granatum Peel Extracts, First published: 20 July 2006 https://doi.org/10.1111/j.13652621.200 3.tb09669.xCitations: 150

Pavelková, A.; Kačániová, M.; Hleba, L.; Petrová, J.; Pochop, J. and Čuboň, J. (2013). Sensory evaluation of chicken breast treated with Oregano essential oil. Animal Sci. Biotech., 46(2): 379383.

PC-STAT, Version I A Copyright. (1985). The University of Georgia

Pearson, D. (1991). The chemical analysis of food. Churchill: New York, London, pp:374-410. Cited from African J. Food Sci., 3(10):316-319.

Podolak, K.; Setser, C. S.; Kastner, C. L. and Zayas, J. F. (1997). Aroma, color and texture of ground beef patties treated with fumaric and lactic acids. J Food Qual., 20: 513-524.

Puupponen-Pimia“, R.; Aura, A. M.; OskmanCaldentey, K. M.; Mylla“rinen, P.; Saarela, M.; Mattila-Sandholm, T. and Poutanen, K. (2002). Development of functional ingredients for gut health Trends in Food Science \& Technology, 13: 3-11.

Rojas, M. C. and Brewer, M. S. (2008). Effect of natural antioxidants on oxidative stability of frozen vacuum packaged beef and pork. J. Food Qual., 31: 173- 
185.

Sacchetti et al., 2008: Sacchetti et al., 200B. Sacchetti, A. Funari, S. Michienzi, S. Di Cesare, S. Piersanti, I. Saggio, E. Tagliafico, S. Ferrari, P.G. Robey, M. Riminucci, P. Bianco Cell, 131 (2007), pp. 324-336

Sahoo and Anjaneyulu 1997: J Sahoo 1, A S Anjaneyulu: Quality improvement of ground buffalo meat by preblending with sodium ascorbate DOI: 10.1016/s0309-1740(97)00018-1

Sallam, K. I. and Samejima, K. (2004). Microbiological and chemical quality of ground beef treated with sodium lactate and sodium chloride during refrigerated storage. Lebensm.-Wiss. Technol., 37: 865-871.

Sangnark, A. and Noomhorm, A. (2003). Effect of particle sizes on functional properties of dietary fibre prepared from sugarcane bagasse. Food Chemistry, 80: 221-229.

Schwarz, S. Schwarz, C. Kehrenberg, T.R. Walsh. 2001. Use of antimicrobial agents in veterinary medicine and food animal production. Int. J. Antimicrob. Agents, 17, pp. 431-437.

Sherwin, E. R. (1998). Oxidation and antioxidants in fat and oil processing. J. Am. Oil Chem. Soc., 55: 809-814.

Solomakos, et al., (2008), Antimicrobial activity of some plant extracts against bacterial strains causing food poisoning diseases, Saudi Journal of Biological Sciences, Volume 25, Issue 2, February 2018, Pages 361-366

Trout (1990): Met-myoglobin percentages of the tested samples were estimated

Trout (1990):Estimation of Met-myoglobin percentages of the tested samples

Viuda-Martos, M.; Ruiz-Navajas, Y.; MartinSánchez, A.; Sánchez-Zapata, E.; Fernández-López, J., Sendra, E.; SayasBarberá, E.; Navarro, C. and PérezÁlvarez J.A. (2012). Chemical, physico-chemical and functional properties of pomegranate (Punica gramatum L.) bagasses powder coproduct. Journal of Food Engineering, 110: 220-224.

Watts, B. M.; Yamaki, G.; Jeffery, L. E. and Elias, L. G. (1989). Basic Sensory Methods for Food Evaluation. 1st Edition, The International Development Research Center Publ., Ottawa, Canada.

WCRF/AICR (2007). World cancer research fund / American institute for cancer research, food, nutrition, physical activity and the prevention of cancer: A global perspective. Washington, DC: AICR (accessed 23 January 2013).

Yi, Z.; Yu, Y.; Liang, Y. and Zeng, B. (2008). In vitro antioxidant and antimicrobial activities of the extract of Pericarpium Citri Reticulatae of a new Citrus cultivar and its main flavonoids, LWTFood Sci. Technol., 41: 597-603.

\section{How to cite this article:}

Hayam Mohamed Ibrahim, Ibrahim Mohamed Hassan and Ahmed Abd El- Ghafar Hammed. 2021. Effect of Adding Lemon Peels Powder on Some Quality Properties of Minced Beef Patty during Refrigerated Storage. Int.J.Curr.Microbiol.App.Sci. 10(05): 809-825. doi: https://doi.org/10.20546/ijcmas.2021.1005.091 